\title{
Relationship between Ownership Concentration and Risk Taking of Listed Commercial Banks in China
}

\author{
Fang $\operatorname{LIU}^{1, \mathrm{a}}$ and Ying $\mathrm{YIN}^{2, \mathrm{~b},{ }^{*}}$ \\ ${ }^{1}$ Post-Doctoral Research Center of Association for the Advancement of Pan-Asian \\ Financial Cooperation and Development in Yunnan, J.X Street 768\# of Cheng Gong \\ New Area, Kunming Yunnan, China \\ ${ }^{2}$ Yunnan University, Cui Hu Street 2\# of Wu Hua Area, Kunming Yunnan, China \\ aliufang198@163.com, b121999053@qq.com \\ * Corresponding author
}

Keywords: Ownership Concentration, Commercial Banks, Risk Taking.

\begin{abstract}
Stable developments of commercial banks play an increasingly important role in national economic development. Moderate ownership concentration not only relates to the risk-taking degree of commercial banks, but also is the key to promoting the healthy development of the whole banking system. Using a panel data of Chinese 16 listed commercial banks over the period 2009-2014 and setting a panel model, this paper examines the relationship between ownership concentration and risk taking by OLS estimator. The results of regression show that ownership concentration has a significant positive effect on risk taking, and there is a inverted-U-shape relationship between the largest shareholding structure concentration and risk taking; while other variables such as State-owned share is also related to risk taking to some extent. Based on the empirical conclusions, this paper puts forward some guidelines to improve risk regulation and reform for commercial banks in China.
\end{abstract}

\section{Introduction}

With the process of international financial integration, our financial industry will be holding a very important role in modern economy, Because of commercial bank is the core of financial industry. Stable development of commercial bank is crucial to the whole financial system and even national economy. The effective reduction of bank risk not only needs the full support of the government and society, but also requires the improvement of self-governance mechanism of commercial bank.

The American Subprime Crisis, which begins in 2007, had bankrupted 49 American commercial banks including the Washington Mutual and caused great unstable of the financial market. Furthermore, it inflicted serious damage on global real economy, and the World Bank find that the flaw of bank's corporate governance is one reason for this subprime crisis.

From financial environment in China point of view, the bank's governance mechanism has been improved after several commercial banks were listed including China Ever bright Bank and the Agricultural Bank of China. But the flaws of ownership structure were still obvious, change the equity structure and improve the corporate governance mechanism are the key and main reform goal for commercial banks at present. 


\section{Listed Commercial Bank's Shareholding Structure and Risk}

\section{Shareholding Structure of Commercial Bank in China}

Shareholding structure is a important part of the corporate governance mechanism. The difference in shareholding structure results in different organization structure, which further influences the different corporate governance mechanism and risk taking. The data of Chinese 16 listed commercial banks in 2014 including proportion of the largest shareholder (CR1), the shareholding ratio of the top five major shareholders (CR5), and leading ten shareholders shares ratio (CR10).

The data shows that proportions of the largest shareholder are Bank of China (66\%) and Citic Industrial Bank (67\%). The shareholding ratio of the top five major shareholders was both $94 \%$. In contrast, proportion of the largest shareholder of The Agricultural Bank of China was $40 \%$, Industrial and Commercial Bank of China was $35 \%$, China Construction Bank was 57\%. But the shareholding ratio of the top five (ten) major shareholder reached to approximate $93 \%$ (94\%), 96\%, respectively.

State-owned share proportion or State-owned legal person shares in commercial bank's stock rights accounted for absolute proportion until the end of 2014. In 16 listed commercial banks, most bank's the largest stock right belongs to country or State-owned legal person. However, in State-owned banks, the higher proportion of largest shareholder is, the more concentrated ownership is, even though the stock system reform has been developed.

In joint-equity commercial banks, proportion of the largest shareholder was less $50 \%$, even the lowest $12 \%$ (Bank of Nanjing), and the shareholding ratio of the top five (ten) major shareholders approximate 60\% (70\%). It is indicated that other shareholders have stock rights over $30 \%$, reflected reasonable structure of stock prices.

\section{Risk Taking of Commercial Bank in China}

The risk taking of commercial banks is essentially possibility of loss in business which banks are operating; it's an intrinsic attribute of business. Because of availability of index data, we measure the risk taking by ratio of Non-performing loan (NPL) in 2014 as shows in figure 1.

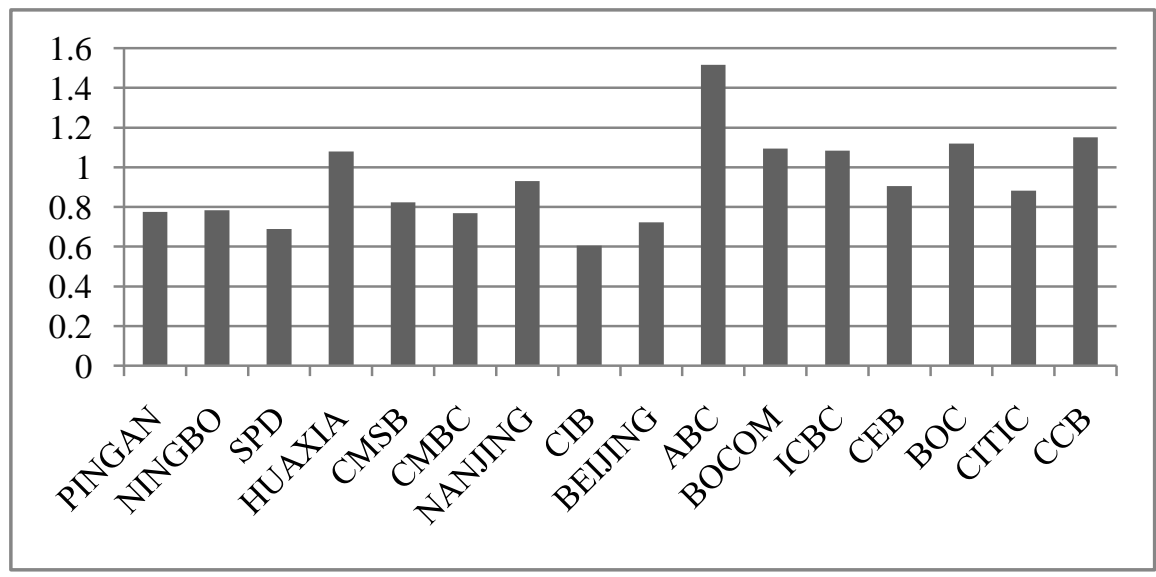

Figure 1. Non-performing Loan Ratio of Listed Commercial Banks

Source: Annual report of listed commercial banks in 2014,RESSET financial database(www.resset.cn)

The Figure 1 shows that the average of Non-performing loan ratio of 16 listed commercial banks is over $0.5 \%$. While, Industrial Bank is the lowest $(0.6 \%)$ and The Agricultural Bank of China is the highest (1.52\%), others were between $0.7 \%$ and 
$1.2 \%$.

From here we can see the rates of non-performing loan of our commercial banks are too excessive to operate business. This situation leads to high risk taking and subject to large losses for commercial banks.

\section{Hypothesis, Variables and Model}

\section{Research hypothesis}

For commercial banks, if the single shareholder holds large proportion of stocks without any restricted from other shareholders, he or she may be using its powerful controlling force to maximize self-interests by investing high-risk projects.

Once big shareholders hold too much stock, however, other shareholders might be dissatisfied and increased their stocks through board of directors in order to reduce holding of large shareholders. Only in this way, risk taking should be reduced in commercial banks.

H1: a U-shape Relationship between Largest Shareholding Concentration and Risk Taking

The definition of Return on Assets (ROA) is how much net margin per asset value created. The higher the ratio of ROA, the higher profit that bank will get. It's guarantee that the bank can reduce risk taking by using financial and material resources sufficiently. In other words, ROA is negative effect on risk taking for any commercial banks.

H 2: ROA is negative effect on Risk Taking

Commercial banks which have too many state-owned stocks can't get out of control from government. They are used to beat the target with policy risk and have a large number of doubtful and bad debts.

The problem of owner absence is easily happened in the case of high ratio of state-owned shares for commercial banks and reduced the supervision and regulation of government on banks, even lead to the problem of administrator's non-pecuniary compensation. All above-mentioned facts are the reasons of risk taking increases sharply for any commercial banks.

H 3: State-owned Share is positively effect on Risk Taking

\section{Variables}

Using risk taking as an explain the phenomenon of commercial banks keep risk inside and relieve it by taking regulatory measure, and that presents as the magnitude risks. Credit risk is an important part of systematic risk in commercial banks, and make use of Non-performing loan ratio as the level of risk taking is a good measures in the paper. Farther, the main explaining variable and three control variables are shows in the table 1 .

Table 1. Main Variables Definition

\begin{tabular}{|c|c|c|}
\hline Name & Code & Meaning \\
\hline $\begin{array}{c}\text { Ratio of the largest } \\
\text { shareholder }\end{array}$ & CR1 $(\%)$ & $\begin{array}{c}\text { The largest shareholder's } \\
\text { share to total share }\end{array}$ \\
\hline the State-owned shares ratio & ST(\%) & $\begin{array}{c}\text { State-owned share to total } \\
\text { share }\end{array}$ \\
\hline the Size of Board & SIZE & Board's membership \\
\hline Return on Assets & ROA $(\%)$ & $\begin{array}{c}\text { Net margin that per asset } \\
\text { value created }\end{array}$ \\
\hline
\end{tabular}

Source: Author Calculator 


\section{The Model}

This paper uses a panel data encompass Chinese 16 listed commercial banks over the period 2009-2014 from RESSET financial database, and the model, which based on the hypothesis 1 to 3 , is written as:

$$
\text { Riskit }=\alpha+\beta 1 \mathrm{CR} 1 \text { it }+\beta 2 \mathrm{ST} \text { it }+\beta 3 \mathrm{BOARD} \text { it }+\beta 4 \mathrm{ROA} \text { it }+ \text { eit }
$$

Where, Risk it represents the ratio of Non-performing loan of bank $\mathrm{i}$ in year $\mathrm{t}, \beta \mathrm{k}(\mathrm{k}$ $=0 \ldots 4)$ represents unknown coefficient, $\varepsilon$ it represents stochastic error term.

As the short panel data and short time span that we can't take unit root test and co-integration test before regression, which can not reflect the relationship between variables and time. Fixed effect, random effect and mixed effect, however, we must to test and choose an accurate model for the panel data.

As we know, there are individual effect and time effect in fixed model, and we should choose the best one by testing. Lastly, our select fixed effect model after testing by F-test and Hausman test with STATA 14.

\section{Empirical Analysis and Results}

\section{Descriptive Statistics}

Table 2 shows that the average of Non-performing loan ratio is $0.94 \%$, the maximum is $2.05 \%$. It explained that the ratio of Non-performing loan of Chinese 16 listed commercial banks has the problem of uneven distribution. The mean value of the proportion of the largest shareholder is $32 \%$, the maximum is $68 \%$ and it shows that there is highly concentrated shareholding in commercial banks.

Table 2. Descriptive Statistics

\begin{tabular}{|l|c|c|c|c|c|c|}
\hline Name & Max & Min & Mean & Median & S.D & Obs \\
\hline RISK & $2.05 \%$ & $0.38 \%$ & $0.94 \%$ & $0.89 \%$ & $0.33 \%$ & 96 \\
\hline CR1 & $68 \%$ & $11 \%$ & $32 \%$ & $21 \%$ & $19 \%$ & 96 \\
\hline ST & $100 \%$ & 0 & $7.28 \%$ & 0 & $20.75 \%$ & 96 \\
\hline SIZE & 30 & 13 & 20.5 & 21 & 3.99 & 96 \\
\hline ROA & $1.47 \%$ & $0.48 \%$ & $1.44 \%$ & $1.15 \%$ & $1.92 \%$ & 96 \\
\hline
\end{tabular}

Source: Author Calculator

While, the maximum of State-owned shares ratio is $100 \%$ and the mean is $7.28 \%$, we can see the State-owned shares of banks is unbalanced. Besides, the maximum of ROA is $1.47 \%$ and the minimum is $0.48 \%$ in the end of table 2 .

\section{Baseline Model Results}

Table 3 shows the results of regression between proportion of the largest shareholder and risk taking. As can be seen in column (1) of Table 3, which shows that proportion of the largest shareholder is positive effect on of non-performing loan ratio at the significance lever 5\%. It's implied that increase in risk taking with the increase in the ratio of the largest shareholder.

In column (2), the coefficient of CR1 and NPL is negative and its quadratic term shows a positive relationship to NPL. That means the increase in risk taking is associated with decrease in the ratio of the largest shareholder and enhance later. All above-mention results, we believe that the result is in according with hypothesis 1 . 
Table 3. The Largest Shareholder Proportion and Risk Taking

\begin{tabular}{|c|c|c|}
\hline Dependent variable=NPL & $(1)$ & $(2)$ \\
\hline CR1 & $0.9646^{* * *}$ & $-3.6955^{*}$ \\
& $(2.395)$ & $6.7828^{* * *}$ \\
& & $(2.233)$ \\
\hline $\mathrm{CR} 1^{2}$ & & $1.1903^{* * *}$ \\
& $0.6236^{* * *}$ & $(4.545)$ \\
\hline Constant & $(4.833)$ & 96 \\
\hline Observations & 96 & 0.110 \\
\hline $\mathrm{R}^{2}$ & 0.038 & 16 \\
\hline Number of sections & 16 & 0.0913 \\
\hline Adjusted-R & 0.0280 & $10 \%, 5 \%$ \\
\hline
\end{tabular}

Notes: the number in brackets is t-values, ${ }^{*}, * *$ and $* * *$ indicate significance levels at the $10 \%, 5 \%$ and $1 \%$, respectively.

\section{Extending Model Results}

Table 4 shows the results of extending model among ROA, the State-owned shares ratio (ST), the size of board (SIZE) and risk taking, respectively.

In column (3)-(5) of Table 4 we estimate the ROA, ST and SIZE on risk taking respectively. The results show that risk taking is negative correlation to ROA and SIZE, but is positively relate to ST. while in column (6) of Table 4, all variables are estimated on risk taking and the sign of coefficient is same as before results. All the results are complying with the hypothesis 1 3 above-mention analysis in the paper.

Table 4. Extending Model Results

\begin{tabular}{|c|c|c|c|c|}
\hline Dependent variable $=\mathrm{NPL}$ & (3) & (4) & (5) & $(6)$ \\
\hline CR1 & & & & $\begin{array}{c}0.7539 * * \\
(2.139)\end{array}$ \\
\hline ROA & $\begin{array}{c}-0.8993 * * * \\
(-3.430) \\
\end{array}$ & & & $\begin{array}{c}-0.7499 * * * \\
(-3.569) \\
\end{array}$ \\
\hline ST & & $\begin{array}{c}0.0066^{* * * *} \\
(3.478) \\
\end{array}$ & & $\begin{array}{c}0.0047 * * \\
(2.340) \\
\end{array}$ \\
\hline SIZE & & & $\begin{array}{l}-0.0094 \\
(-0.824)\end{array}$ & $\begin{array}{l}-0.0013 \\
(-0.150)\end{array}$ \\
\hline Constant & $\begin{array}{c}1.9652 * * * \\
(6.528)\end{array}$ & $\begin{array}{c}0.8908 * * * \\
(73.912)\end{array}$ & $\begin{array}{c}1.1246^{* * * *} \\
(4.826)\end{array}$ & $\begin{array}{c}1.5492 * * * \\
(4.955)\end{array}$ \\
\hline Observations & 96 & 96 & 96 & 96 \\
\hline $\mathrm{R}^{2}$ & 0.211 & 0.139 & 0.013 & 0.307 \\
\hline Number of sections & 16 & 16 & 16 & 16 \\
\hline Adjusted-R ${ }^{2}$ & 0.203 & 0.130 & 0.00260 & 0.277 \\
\hline
\end{tabular}

Notes: The number in brackets is t-values, ${ }^{*}, * *$ and $* * *$ indicate significance levels at the $10 \%, 5 \%$ and $1 \%$, respectively.

\section{Conclusions}

Our analysis indicates that ownership concentration has a significant effect on risk taking in commercial banks. For a sample of 16 listed commercial banks in China, we find that there is a U-shape relationship between largest shareholding concentration and risk taking, and ROA, SIZE are significantly negative effect on risk taking, but ST is a positive associated with risk taking.

One should be careful in attaching normative implication to these findings. Yet, the results report in this paper may provide some guidelines to policymakers. For example, in an era of financial reform, government should restrict the largest shareholding of 
stockholder and control the size of board in order to push market-oriented reform for commercial banks. A bank that undergoes rapid growing ROA will benefit to reduce the level of risk taking and decrease the State-owned shareholding ratio is also good for the development of commercial banks in the nearly future.

\section{Acknowledgement}

This paper is supported by the young project of Yunnan Provincial Department of Science and Technology "The Effects of RMB Cross-Border Direct Investment and Financing in Yunnan: Based on the Opening DSGE Model" (Grant No.2015FD017) and also is supported by the $\mathrm{PhD}$ fund of Yunnan Normal University that is "Research on the Interest Groups and Finance Development in Theoretic and Empirical" (Grant No.140082).

\section{References}

[1] H. Abouelsood, Journal of Biomedical Materials Research.12. 6 (1978)867-75.

[2] H. Pan, M. Yi, H. Liu, Luojia Management Review. 2014, in Chinese.

[3] M. M. Hanafi, F. Santi, Muazaroh, Eurasian Economic Review. 3. 2(2013)183-202.

[4] G. Gürsoy, K. Aydoğan, Emerging Markets Finance \& Trade. 38.6(2002)6-25.

[5] P. Chalermchatvichien, S. Jumreornvong, P. Jiraporn, et al., Journal of Multinational Financial Management. 28 (2014)28-46.

[6] Y. Boujelbene, N. Zribi, International Journal of Corporate Governance. 12. 3(2009)259-270.

[7] T. A. Barry, L. Lepetit, A. Tarazi, Journal of Banking \& Finance. 35.5(2011)1327-1340.

[8] Y. Dong, C. Meng, M. Firth, et al., International Review of Financial Analysis. 36(2014)120-130.

[9] S. Srairi, Borsa Istanbul Review. 13.4(2013)115-127. 